\title{
Additional use of autogenous periosteal barrier membrane combined with regenerative therapy in the interproximal intrabony defects: case series
}

\author{
Hyun-Joo Kim, Hyung-min Kim, Ju-Youn Lee* \\ Department of Periodontology, School of Dentistry and Dental Research Institute, Pusan National University, Yangsan, \\ Republic of Korea
}

\begin{abstract}
Regenerative therapy in an interproximal intrabony defect is a challenge due to unaesthetic appearance after surgery. In this article, we introduce a case series of additional use of autogenous periosteal barrier membrane combined with bovine bone mineral and enamel matrix derivative (EMD) in interproximal periodontal intrabony defects to overcome an aforementioned shortcoming. During the periodontal regenerative surgery, autogenous periosteal membrane was additionally adopted besides xenograft material and EMD. Clinical and radiographic examinations were performed before surgery and 6 months after surgical treatment. All clinical parameters were improved and the intrabony defects were resolved on the radiography 6 months after surgery. Moreover, soft tissue esthetics such as the contour of interdental papilla was better than that of conventional regenerative therapy. Periodontal regenerative therapy using several graft materials and bioactive materials was effective in the treatment of periodontal intrabony defect. Moreover, using of autogenous periosteal barrier membrane combined with xenograft and EMD has additional effect for the treatment of an interproximal intrabony defect in terms of augmentation of interdental soft tissue volume. (J Dent Rehabil Appl Sci 2017;33(3):230-7)
\end{abstract}

Key words: enamel matrix proteins; guided tissue regeneration; periosteum

\section{Introduction}

The residual periodontal pocket of $>5 \mathrm{~mm}$ after the completion of active periodontal therapy is associated with an increased risk of disease progression. ${ }^{1-3}$ In addition, intrabony defects have been shown to worsen the long-term prognosis of the teeth. ${ }^{4}$ To treat intrabony defects, several approaches, including scaling root planing (SRP), open flap debridement, and resective and regenerative surgery, have been employed for several decades. ${ }^{5,6}$

*Correspondence to: Ju-Youn Lee

Professor, Department of Periodontology, School of Dentistry, Pusan National University, Dental Research Institute, 20 Geumo-ro, Beomeo-ri, Mulgeum-eup, Yangsan, 50612, Republic of Korea

Tel: +82-55-360-5202, Fax: +82-55-360-5194, E-mail: heroine@pusac.ac.kr

Received: July 17, 2017/Last Revision: July 31, 2017/Accepted: August 3, 2017
Several bone graft materials, bioactive materials and growth factors can be adopted for regenerative surgery. $^{7}$

The use of an enamel matrix derivative (EMD), an extract of the enamel proteins including amelogenins of various molecular weights, would generate fewer post-operative complications. ${ }^{8}$ Systematic reviews of several clinical trials have shown that some of these materials, when used in conjunction with surgical approaches designed to facilitate maximal preservation of soft and hard tissues, may indeed result in

Copyright(C 2017 The Korean Academy of Stomatognathic Function and Occlusion. (c) It is identical to Creative Commons Non-Commercial License. 
superior clinical outcomes. ${ }^{9}$ Xenografts can augment the effects of EMD in reducing the probing pocket depth (PPD), improving the clinical attachment level (CAL), and promoting defect filling compared to the EMD alone or open flap debridement in the treatment of intrabony periodontal defects. ${ }^{10}$ Despite the advantages of regenerative therapy, the achievement of primary soft tissue closure and revascularization are difficult, particularly in the interdental area. After periodontal surgery, a soft tissue crater is common in the interdental area, which is problematic for patients and periodontists. For better vascularization, several incision or surgical techniques [i.e. simplified papilla preservation flap $(\mathrm{SPPF})^{11}$ etc.] have been proposed, but interdental soft tissue depression is still problem.

A periosteal graft in intrabony defects has the potential to stimulate bone formation and reduce the PPD when used as a graft material and barrier membrane. ${ }^{12,13}$ Moreover, the periosteal graft can augment a soft tissue volume in the field of periodontal surgery. This article reports 3 cases of the additional use of a periosteal membrane with a xenograft and EMD in interdental intrabony defects.

\section{Case description}

\section{Case 1}

A 46-year-old woman with the chief complaint of dull pain in the mandibular left first premolar (\#34) visited the Department of Periodontology, Pusan National University Dental Hospital. The patient had no remarkable systemic disease affecting the dental condition. A clinical examination revealed $7 \mathrm{~mm}$ PPD and $2 \mathrm{~mm}$ gingival recession on the mesiobuccal aspect on \#34 (Table 1) and no tooth mobility. The gingival depression was noticeable at the mesiobuccal site of \#34 and the gingival biotype was the thin type (Fig. 1A). In the periapical radiograph, an intrabony defect was detected on the mesial side of \#34 (Fig. 2A).

Regenerative surgical therapy was considered after the initial periodontal treatment, including oral hygiene instruction and SRP. On the other hand, after regenerative surgery, the depression of the interdental papilla would be inevitable because the gingival biotype was thin and the location of the intrabony defect was interproximal. The patient was concerned about the wide embrasure and unaesthetic appearance. Therefore, several alternatives for regenerative surgery were considered and a decision was made to adopt an additional periosteal graft with a bovine bone graft and EMD (Emdogain ${ }^{\circledR}$, Straumann, Basel, Switzerland).

All the surgical procedures were performed by the same periodontist (HK). After local anesthesia, access to the defect was achieved using a sulcular incision, SPPF and limited mesiodistal extension of the buccal and lingual flap of the one tooth neighboring the defect, and no vertical releasing incisions were

Table 1. Comparison of the clinical parameters of 3 cases $(\mathrm{mm})$

\begin{tabular}{ccccccccccccccccccc}
\hline & \multicolumn{1}{c}{ PPD } & \multicolumn{1}{c}{ Baseline } & \multicolumn{1}{c}{ 6 Months } & \multicolumn{4}{c}{ Baseline } & \multicolumn{4}{c}{ 6 Months } & \multicolumn{4}{c}{ BEseline } & \multicolumn{3}{c}{ 6 Months } \\
& ML & L & DL & ML & L & DL & ML & L & DL & ML & L & DL & ML & L & DL & ML & L & DL \\
& MB & B & DB & MB & B & DB & MB & B & DB & MB & B & DB & MB & B & DB & MB & B & DB \\
\hline Case 1 & 3 & 4 & 4 & 1 & 1 & 1 & 4 & 6 & 5 & 1 & 1 & 1 & 1 & 2 & 1 & 0 & 0 & 0 \\
(\#34) & 7 & 2 & 5 & 2 & 1 & 2 & 9 & 5 & 6 & 4 & 5 & 4 & 2 & 3 & 1 & 2 & 4 & 2 \\
Case 2 & 7 & 3 & 3 & 3 & 2 & 3 & 9 & 5 & 4 & 5 & 3 & 4 & 2 & 2 & 1 & 2 & 1 & 1 \\
(\#37) & 5 & 3 & 3 & 4 & 3 & 3 & 6 & 5 & 4 & 6 & 3 & 3 & 1 & 2 & 1 & 2 & 0 & 0 \\
Case 3 & 5 & 5 & 3 & 3 & 1 & 2 & 5 & 5 & 3 & 5 & 3 & 4 & 0 & 0 & 0 & 2 & 2 & 2 \\
(\#34) & 4 & 2 & 2 & 3 & 1 & 2 & 6 & 4 & 3 & 4 & 2 & 2 & 2 & 2 & 1 & 1 & 1 & 0 \\
\hline
\end{tabular}

PPD, probing pocket depth; CAL, clinical attachment level; RE, recession; ML, mesiolingual; L, midlingual; DL, distolingual; MB, mesiobuccal; B, midbuccal; DB, distobuccal. 
made (Fig. 1B). After minimal flap elevation, a 2-wall intrabony defect was confirmed and the defect size was 3 (width) $\times 6$ (depth) $\mathrm{mm}$ (Fig. 1B). The root surface and intrabony defect were debrided thoroughly and the root surface was conditioned using $24 \%$ ethylenediaminetetraacetic acid (PrefGel, Straumann) for 2 minutes. After rinsing with saline, EMD was applied to the root surface and the defect was filled with a combination of EMD + deproteinized bovine bone mineral (DBBM, Bio-Oss ${ }^{\circledR}$, Geistlich, Wolhusen, Switzerland).

A $3 \times 14 \mathrm{~mm}$ sized and $1.0 \mathrm{~mm}$ thick autogenous periosteal graft was harvested from the palatal area. Briefly, after application of local anesthesia, a splitthickness flap "trap door", which consisted of 1 horizontal and 2 vertical incisions, was elevated to access the donor graft tissue. After elevating the split-thickness flap, 4 incisions (mesial, distal, coronal, and apical) were made to the bone surface. Connective tissue with periosteum was obtained for use as a biologic barrier membrane. The graft was positioned over the combination of EMD + DBBM, stuck under the buccal and lingual flap and sutured with the overlying flap. Finally, the overlying flap was repositioned to cover as much of the periosteal graft as possible (Fig. 1C, 1D).

Amoxicillin $500 \mathrm{mg}$ and acetaminophen $500 \mathrm{mg}$ were administered three times a day for 3 days. The patient was instructed to avoid mechanical cleaning in the surgical area and to rinse with $0.12 \%$ chlorhexidine (Hexamedine ${ }^{\circledR}$, Bukwang pharm, Seoul, Korea) twice a day for 1 month. The sutures were removed 14 days after surgery and supportive postoperative care was carried out monthly after surgery for 6 months. At 6 months after surgery, clinical and radiographic examinations were carried out.

The healing was uneventful and the volume and morphology of the interdental soft tissue was improved at 6 months after surgery (Fig. 3D). The PPD was reduced and the clinical attachment level was gained (Table 1). In addition, the graft material appeared to be well mixed with the surrounding bone (Fig. 2D).
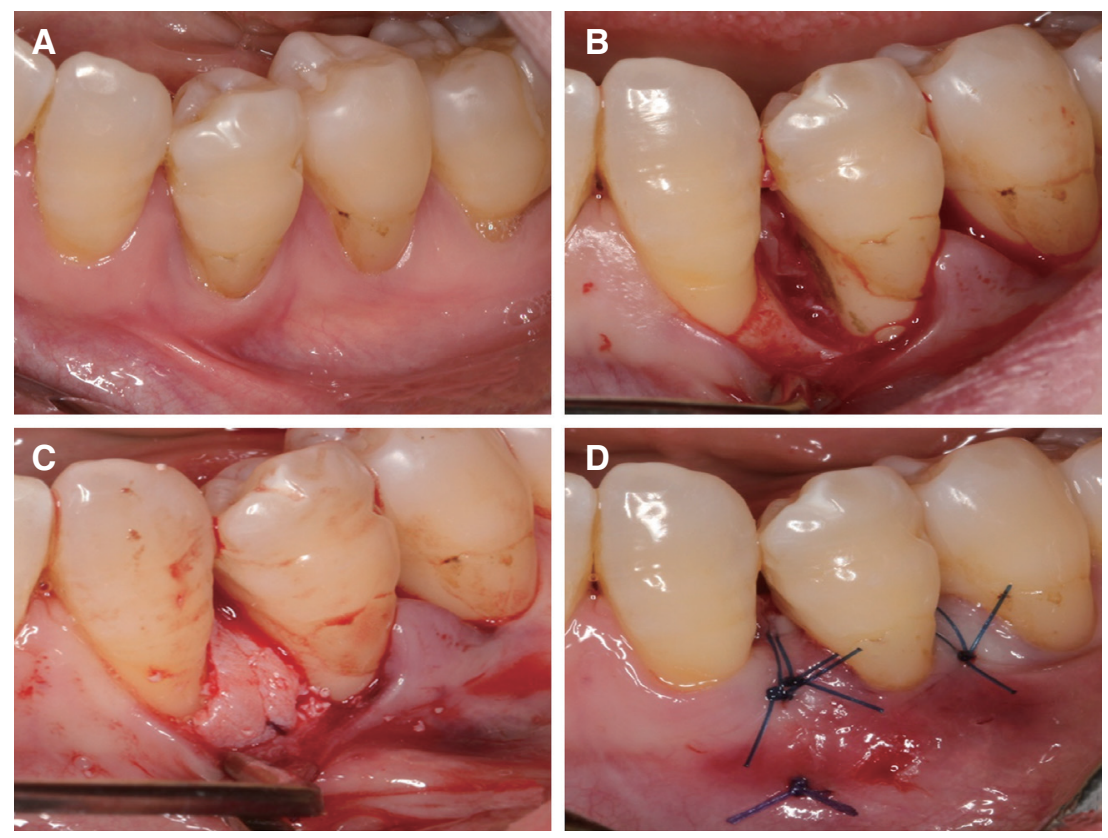

Fig. 1. Regenerative surgical sequence with additional use of autogenous periosteal membrane graft combined with xenograft and Emdogain ${ }^{\circledast}$. (A) Baseline PPD $7 \mathrm{~mm}$ and recession $2 \mathrm{~mm}$. (B) After flap reflection, 2-wall intrabony defect with $6 \mathrm{~mm}$ depth. (C) Autogenous periosteal membrane graft combined with xenograft and Emdogain ${ }^{\circledR}$. (D) Primary closure of the overlying flap. 

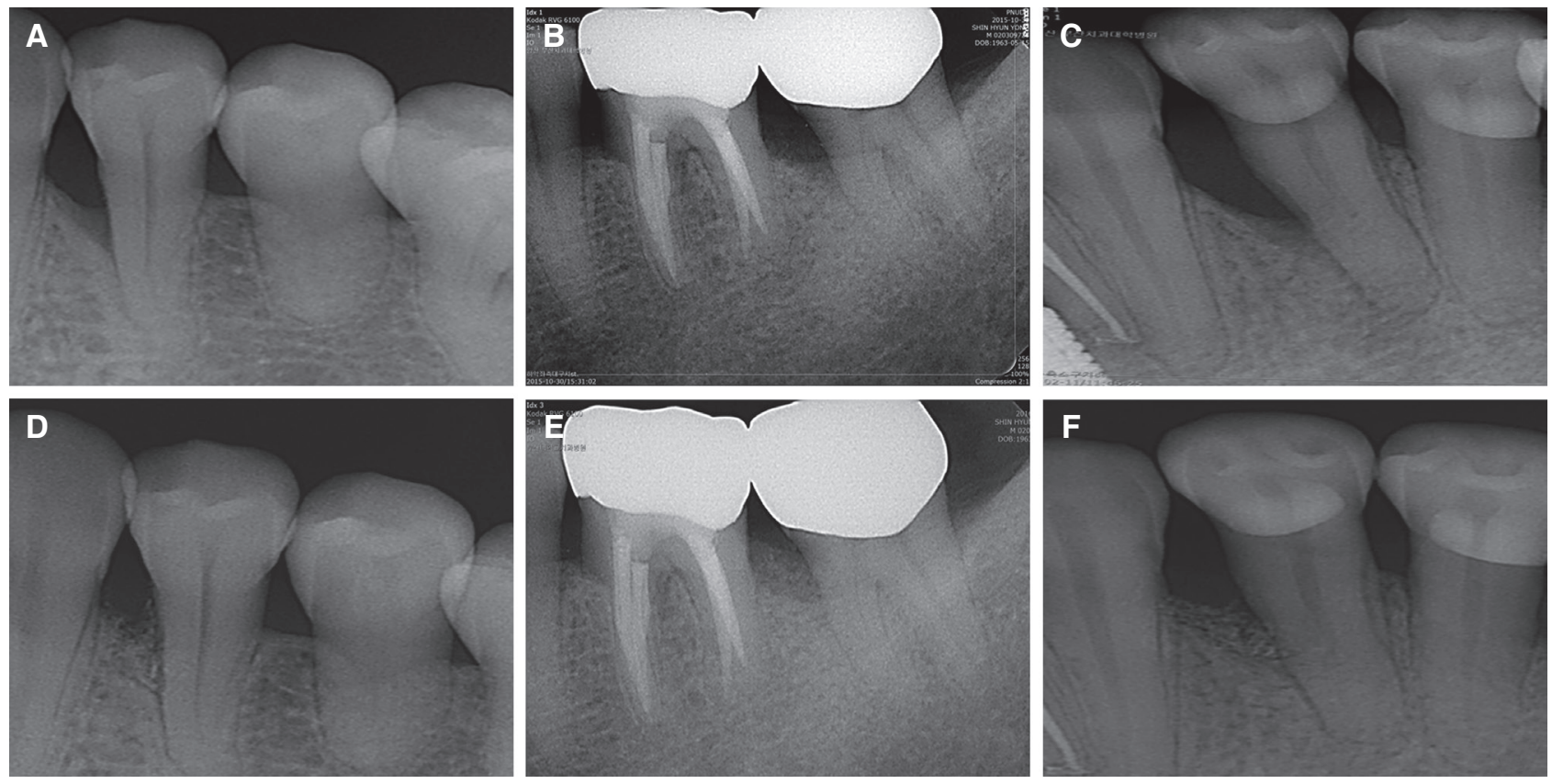

Fig. 2. Periapical radiograph before surgery $(A, B, C)$ and 6 months after surgery $(D, E, F)$. Note the resolution of intrabony defect after surgery (D, E, F).
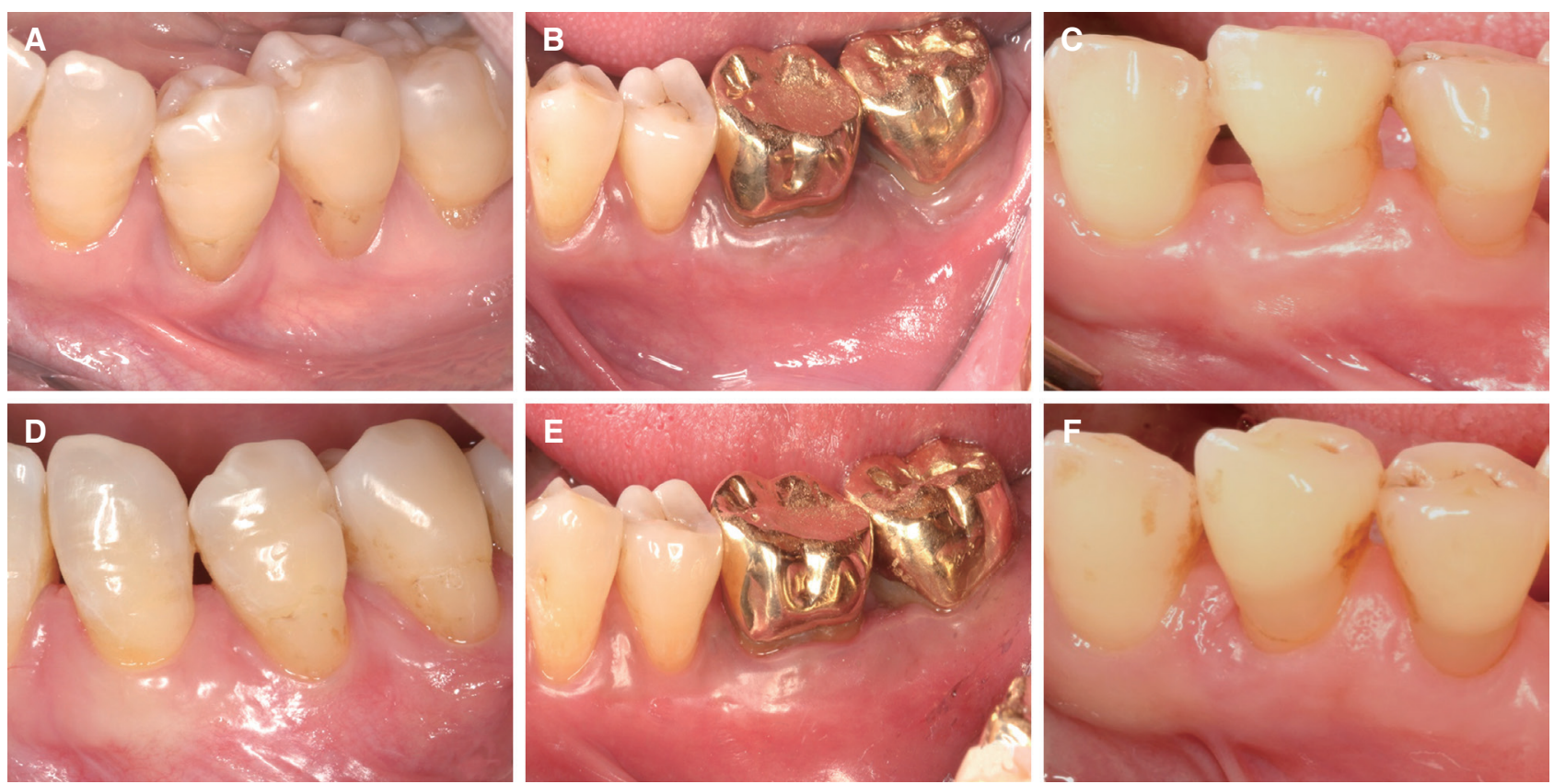

Fig. 3. Clinical presentation of 3 cases. Preoperative view (A, B, C) and 6 months after regenerative surgery (D, E, F). Note the augmentation of the volume of the interdental papilla after surgery (D, E, F). 


\section{Case 2}

A 53-year-old man with a non-contributory medical history presented at the Department of Periodontology, Pusan National University Dental Hospital, with the chief complaint of dull pain of the mandibular left second molar (\#37). He smoked approximately 10 cigarettes per day. The PPD was 7 $\mathrm{mm}$ (mesiolingual) and $5 \mathrm{~mm}$ (mesiobuccal) and a 1 - $2 \mathrm{~mm}$ gingival recession was detected at the mesial side of \#37 (Fig. 3B). A radiographic examination revealed an intrabony defect with a moderate depth at the mesial side of \#37 (Fig. 2B). An additional periosteal graft with a bovine bone graft and EMD were selected because the clinical situation and defect morphology were similar to those of case 1. After flap elevation and thorough debridement, a 2-wall intrabony defect (depth: $5 \mathrm{~mm}$, width: $5 \mathrm{~mm}$ ) was detected. An autogenous periosteal membrane (size: $5 \times 14 \times 1.0 \mathrm{~mm}$ ) was obtained from the left palate and EMD + DBBM + periosteal membrane were applied using the same protocol of case 1 .

The soft tissue volume on the mesial side of \#37 was improved, even though a shallow crater of soft tissue was detected 6 months after surgery (Fig. 3E), but the defect fill was evident (Fig. 2E).

\section{Case 3}

A 60-year-old woman presented to the clinic complaining of dull pain in the mandibular left first premolar (\#34). The clinical and radiographic examinations revealed an intrabony defect and a PPD of 5 $\mathrm{mm}$ (mesiolingual), $4 \mathrm{~mm}$ (mesiobuccal) and a $2 \mathrm{~mm}$ gingival recession at the mesial side on \#34 (Fig. 2C, 3C, Table 1). The same regenerative surgical protocol was selected because of the similar situation in the preceding 2 cases. A 3-wall intrabony defect (depth: $8 \mathrm{~mm}$, width: $5 \mathrm{~mm}$ ) and local factors were observed after flap elevation.

The healing was uneventful and the interdental soft tissue volume was well maintained (Fig. 3F). In addition, the bone graft materials appeared to be well mixed with the surrounding bone (Fig. 2F).

\section{Discussion}

Several problems, such as gingival recession and soft tissue crater are inevitable after periodontal surgery, particularly in regenerative surgery. Moreover, if the target site is the interproximal area, it would be more severe than in the buccal or lingual surface because the interdental papilla and connective tissue in the col area are devoid of adequate blood supply and healing capacity. To overcome these problems, several approaches (minimally invasive surgical technique, ${ }^{6} \mathrm{SPPF},{ }^{11}$ single flap approach ${ }^{14}$ etc.) have been introduced. Despite the careful minimally invasive surgeries, in which a simplified papilla preservation flap was used, interproximal wound dehiscence with membrane exposure occurred in the majority of the regenerative surgical treatment. ${ }^{15}$ Regenerative surgery of interproximal intrabony defect is very difficult to perform, particularly in esthetics sensitive areas.

Moreover, meta-analysis of the effects of membrane exposure or wound dehiscence on the clinical outcome, showed that the sites with an exposed membrane had a negative effect on the regeneration such as the gain of the clinical attachment level. ${ }^{16}$ Bioactive materials and growth factors are introduced to boost the effects of regenerative surgery and although the actual clinical advantages are still uncertain, the EMD would generate fewer post-operative complications and better soft tissue healing. ${ }^{8}$ The soft tissue healing was more favorable and speedy when an EMD was added to the regenerative periodontal surgery from the author's clinical experiences.

Previous studies ${ }^{17,18}$ on the use of autogenous periosteal graft as barriers in intrabony defects reported greater approximately $1 \mathrm{~mm}$ CAL gain over sites treated by open flap debridement procedure alone. A periosteal graft in intrabony defects has the potential to stimulate bone formation and reduce the PPD when used as a graft material and barrier membrane. ${ }^{12,13}$ In these cases, EMD and autogenous periosteal membrane were adopted to enhance the outcome of regenerative surgery and soft tissue volume. The healing of 3 cases was uneventful and the morbidity and discomfort of the patients was 
minimal. Six months after surgery, the PPD had decreased by $2.83 \mathrm{~mm}, 1.17 \mathrm{~mm}$, and $1.83 \mathrm{~mm}$, respectively. In addition, the depth of the intrabony defect decreased significantly according to the radiography and the clinical attachment level gain were $3.16 \mathrm{~mm}, 1.50 \mathrm{~mm}$, and $1.00 \mathrm{~mm}$, respectively. After this regenerative surgical protocol, not only the gingival margin didn't depressed severely, but also the soft tissue volume augmented aesthetically. These findings are in agreement with the results of a previous study. ${ }^{19}$

Although the trend of surgical treatment shifts to a minimally invasive surgery nowadays, the additional use of an autogenous periosteal membrane and EMD has a beneficial effect on regenerative surgery in the interdental area. In particular, in esthetic sensitive areas and the thin gingival biotype, these treatment options would be helpful for overcoming the unaesthetic problems after regeneration periodontal surgery.

\section{Acknowledgements}

This work was supported by a 2-Year Research Grant of Pusan National University.

\section{ORCID}

Hyun-Joo Kim https://orcid.org/0000-0001-7553-6289

Hyung-min Kim https://orcid.org/0000-0003-2617-4140

Ju-Youn Lee https://orcid.org/0000-0002-0772-033X

\section{References}

1. Claffey N, Egelberg J. Clinical indicators of probing attachment loss following initial periodontal treatment in advanced periodontitis patients. J Clin Periodontol 1995;22:690-6.

2. Matuliene G, Pjetursson BE, Salvi GE, Schmidlin K, Brägger U, Zwahlen M, Lang NP. Influence of residual pockets on progression of periodontitis and tooth loss: results after 11 years of maintenance. J Clin Periodontol 2008;35:685-95.

3. Papapanou PN, Wennström JL. The angular bony defect as indicator of further alveolar bone loss. J
Clin Periodontol 1991;18:317-22.

4. Papapanou PN, Tonetti MS. Diagnosis and epidemiology of periodontal osseous lesions. Periodontol 2000 2000;22:8-21.

5. Cortellini P, Labriola A, Tonetti MS. Regenerative periodontal therapy in intrabony defects: state of the art. Minerva Stomatol 2007;56:519-39.

6. Cortellini P, Tonetti MS. A minimally invasive surgical technique with an enamel matrix derivative in the regenerative treatment of intra-bony defects: a novel approach to limit morbidity. J Clin Periodontol 2007;34:87-93.

7. Sculean A, Nikolidakis D, Nikou G, Ivanovic A, Chapple IL, Stavropoulos A. Biomaterials for promoting periodontal regeneration in human intrabony defects: a systematic review. Periodontol 2000 2015;68:182-216.

8. Esposito M, Grusovin MG, Papanikolaou N, Coulthard P, Worthington HV. Enamel matrix derivative (Emdogain) for periodontal tissue regeneration in intrabony defects. A Cochrane systematic review. Eur J Oral Implantol 2009;2:247-66.

9. Kao RT, Nares S, Reynolds MA. Periodontal regeneration - intrabony defects: a systematic review from the AAP Regeneration Workshop. J Periodontol 2015;86:S77-104.

10. Lekovic V, Camargo PM, Weinlaender M, Nedic M, Aleksic Z, Kenney EB. A comparison between enamel matrix proteins used alone or in combination with bovine porous bone mineral in the treatment of intrabony periodontal defects in humans. J Periodontol 2000;71:1110-6.

11. Cortellini P, Prato GP, Tonetti MS. The simplified papilla preservation flap. A novel surgical approach for the management of soft tissues in regenerative procedures. Int J Periodontics Restorative Dent 1999;19:589-99.

12. Saimbi CS, Gautam A, Khan MA, Nandlal. Periosteum as a barrier membrane in the treatment of intrabony defect: a new technique. J Indian Soc Periodontol 2014;18:331-5.

13. Lekovic V, Kenney EB, Carranza FA, Martignoni M. The use of autogenous periosteal grafts as barriers for the treatment of Class II furcation involvements in lower molars. J Periodontol 1991;62:775- 
80.

14. Trombelli L, Simonelli A, Pramstraller M, Wikesjö UM, Farina R. Single flap approach with and without guided tissue regeneration and a hydroxyapatite biomaterial in the management of intraosseous periodontal defects. J Periodontol 2010;81:1256-63.

15. Rakmanee T, Griffiths GS, Auplish G, Darbar U, Petrie A, Olsen I, Donos N. Treatment of intrabony defects with guided tissue regeneration in aggressive periodontitis: clinical outcomes at 6 and 12 months. Clin Oral Investig 2016;20:1217-25.

16. Machtei EE. The effect of membrane exposure on the outcome of regenerative procedures in humans: a meta-analysis. J Periodontol 2001;72:512-6.
17. Kwan SK, Lekovic V, Camargo PM, Klokkevold PR, Kenney EB, Nedic M, Dimitrijevic B. The use of autogenous periosteal grafts as barriers for the treatment of intrabony defects in humans. J Periodontol 1998;69:1203-9.

18. Gamal AY, Mailhot JM. A novel marginal periosteal pedicle graft as an autogenous guided tissue membrane for the treatment of intrabony periodontal defects. J Int Acad Periodontol 2008;10:106-17.

19. Tonetti MS, Prato GP, Cortellini P. Factors affecting the healing response of intrabony defects following guided tissue regeneration and access flap surgery. J Clin Periodontol 1996;23:548-56. 


\section{치간부 골내낭의 치주재생치료에서 골막이식의 부가적 사용 증례}

\section{김현주, 김형민, 이주연*}

부산대학교 치의학전문대학원 치주과학교실

치간부 골내낭의 치주재생치료는 수술 후 발생할 수 있는 비심미성 때문에 치과의사에게 힘든 과제이다. 본 연구에서는 이러한 문제점을 해결하기 위해 치간부 골내낭의 bovine bone mineral과 enamel matrix derivative (EMD)를 이용한 재 생 수술에 골막을 포함한 결합조직 이식을 동반한 임상증례를 소개하고자 한다. 임상적 및 방사선학적인 검사는 술 전과 수술 6개월 이후 시행하였다. 모든 임상 지표들이 개선되었고, 방사선학적 검사에서 골내낭이 감소함을 확인할 수 있었 다. 또한, 부가적인 결합조직이식을 통해 치간부 연조직의 증대 및 형태 개선으로 인한 심미성이 증진되는 효과도 확인할 수 있었다.

(구강회복응용과학지 2017;33(3):230-7)

주요어: 법랑기질단백질; 조직유도재생술; 골막

*교신저자: 이주연

(50612)경상남도 양산시 물금읍 금오로 20 부산대학교 치의학전문대학원 치주과학교실

Tel: 055-360-5202 || Fax: 055-360-5194 | E-mail: heroine@pusac.ac.kr

접수일: 2017년 7월 17일 | 수정일: 2017년 7월 31일 || 채택일: 2017년 8월 3일 